\title{
Evaluation of Endogeneity of Money Supply under Inflation Targeting Implementation in Turkey
}

\section{Baki DEMIREL ${ }^{1}$}

\section{ARTICLE INFO}

\section{Article History:}

Date Submitted: 12.07.2018

Date Accepted: 20.09.2018

\section{JEL Classification:}

E40

E51

E52

\section{Keywords:}

Money Supply,

Granger Causality Test, Error Correction Model.

\begin{abstract}
This study aimed to question how successful the CBRT could be in the process of determining the money supply by acting in all these motivational conditions. To achieve this aim M3 as a proxy variable to the money supply, the banking sector loan volume as a proxy for the money demand has been dealt with. The study tested the causality relationship between variables using the Granger Causality Test and Error Correction Model.
\end{abstract}

According to the results of the Granger Causality Test, in the long run, the direction of causality between the money supply and credit expansion is straightforward from the money supply to the credit extension.

According to the findings of the Error Correction Model, there is a positive and statistically significant relationship between money supply and credit expansion in the short term. Credit expansion increases money supply.

\footnotetext{
${ }^{1}$ Asst.Prof. Economics Department of University Of Gaziosmanpaşa, Tokat/Turkey, baki.demirel@ gop.edu.tr
} 


\section{Introduction}

The implementation of inflation targeting is a system in which the direct target of inflation is taken as the nominal anchor without intermediate targets. Under this system, the main task of the Central Bank is to ensure price stability. In this system, the Central Bank's main policy instrument is the policy interest rate. The determination of the policy interest rate is based on the Taylor Rule, which we can express as a rule.

Taylor Rule has a stance close to the views we can express as Classical-Neo Classical / Monetarist or Neo Classical-Keynesian synthesis. Because pure Keynesian thought accepts activist / fine tuning politics instead of politics according to the rule. According to the rule, the money supply is determined externally by the Central Bank.

On the other hand, the Central Bank does not control the money supply in the implementation of inflation targeting, which is based on the Central Bank's use of vehicle variable policy rate.

This reinforces the idea that monetary supply may be intrinsic under inflation targeting, that is, money supply may be determined by money demand.

Turkey in the 2002-2005 period since 2006, while implicitly has the ability to be examples of countries that fully implement inflation targeting these studies. After the implementation of the inflation targeting, the CBRT (Central Bank of Republic of Turkey) uses the policy interest rate as the main policy instrument.

However, after 2010, the CBRT, which also took financial stability alongside the price stability target, began to use liquidity management as a policy tool. The basic motivation of this work also emerged after this point. The extent to which the CBRT's liquidity management, which uses the policy phase as its main policy tool, can dominate the money supply is a matter of debate. Especially the failure of inflation targets excluding 2009 strengthens this debate.

This study aimed to question how successful the CBRT could be in the process of determining the money supply by acting in all these motivational conditions. To achieve this 
aim M3 as a proxy variable to the money supply, the banking sector loan volume as a proxy for the money demand has been dealt with. The study tested the causality relationship between variables using the Granger Causality Method.

\section{Literature Survey}

The issue of endogenous money supply is addressed in Post-Keynesian theory. According to Post Keynesian, money supply is determined by credit demand. Post Keynesian Macroeconomics provides provides a critical linkage between the financial and real sectors, with the link running predominantly from credit to money to economic activity. (Palley, 2008).

Money Politics; such as money supply, short-term interest rates or exchange rates, which are based on the control of variables that are determinants of production and inflation, and control belongs to the central banks. In the long run, while the monetary policy is only effective on the general level of prices, the monetary policy in the short run can affect both the inflation and the production level, since prices and wages cannot be adjusted quickly (TCMB 2013)

Sabri Nayan et al (2013) paper, data from 177 countries were analyzed using panel data method from 1970 to 2011. The findings are that the money supply is endogenous as the Post Keynesian theory explains.

Ahmad and Ahmed (2006) show that using the standard Granger causality method, the money supply of Pakistan for the period of 1980-2003 is determined endogenously in the shortest period. This paper also shows that the Central Bank of Pakistan is influencing the money supply in the long run.

Cepni and Güney (2017) paper in period from 2006 to 2015 using data analysis that has acted in accordance with what the theory of money supply in Turkey. This paper's the direction of the findings that money supply determined by of bank loans in Turkey. So, in Turkey's economy and banks' central bank that fully satisfies the total money demand is supporting the endogenous opinion in a sense. 


\section{The Model and Data Set}

In this study, we refer to the model used in the study of Ahmed and Ahmed (2006). The econometric model of this study is as follow:

$$
M s_{t}=\beta_{0}+\beta_{1} M s_{-1 t}+\beta_{2} C R D_{t}+\varepsilon_{t}
$$

Where, Mst; Money Supply, Mst-1; Monetary Base, CRD; Total Credit of Turkish Economy and $\varepsilon_{t}$ is Error Term.

The data has been collected from CBRT dataset and the descriptive statistics of the series are reported in Table 1.

Table 1. Statistic (2015-2018 daily data).

\begin{tabular}{llll}
\hline & MS & MS -1 & CRD \\
\hline Mean & 1275495. & 1342151. & 1528497. \\
\hline Std. Dev. & 425994.8 & 506901.0 & 497916.6 \\
\hline Skewness & -1.920906 & -1.539024 & -1.762173 \\
\hline Kurtosis & 5.800932 & 4.602379 & 5.788249 \\
\hline Jarque-Bera & 141.2796 & 75.76426 & 126.2209 \\
\hline Probability & 0.000000 & 0.000000 & 0.000000 \\
\hline Observations & 152 & 152 & 152 \\
\hline
\end{tabular}

Note: Jargue-Bera shows the test results of normal distribution, and null hypothesis depicts that series is normally distributed. The results Show that all serias are normality.

We now turn the issue of formal tests of whether an observed data series is generated by a stationary or non-stationary process, such as, ADF. In this study, the Augmented Dickey Fuller (ADF) (Dickey and Fuller, 1979) test was applied. The findings of the unit root tests can be found from Table 2. 
Table 2. Unit Root Test.

\begin{tabular}{lll}
\hline Variables & ADF test Level & ADF test First Differance \\
\hline Ms & $-9.70 * * *$ & $-9.68 * * *$ \\
\hline Ms-1 & $-10.77 * * *$ & $-14.77 * * *$ \\
\hline CRD & $-6.11 * * *$ & $-9.94 * * *$ \\
\hline
\end{tabular}

Note: $* * *, * *$ and $*$ indicate the $1 \%, 5 \%$ and $10 \%$ levels of significance, respectively; the null hypothesis is rejected and the alternative hypothesis, saying that series is stationary is not rejected. The lag order for ADF test is selected.

The results from Table 2 show that all variables are stationary at the level.

\section{Granger Causalty Test: Long Run Analyses.}

"Using Daily data described above, we use Granger causality test to examine the endogeneity of money supply. Granger (1969) causality test is used to infer statistical precedence of information. ' $y$ ' is said to be granger caused by ' $x$ ' if ' $x$ ' helps in the prediction of ' $y$ '. In Two-way causality there is a feedback mechanism. ' $x$ ' granger causes $y$ does not imply that ' $y$ ' is the manifestation of ' $x$ '. Following is the formulation of granger causality test: The fundamental assumption of granger causality test is that the concerned series should be a stationary process" (Ahmed and Ahmed, 2006).

$$
\begin{aligned}
& Y_{t}=\alpha_{0}+\alpha_{1} Y_{t-1}+-----+\alpha_{T} Y_{t-T}+\beta_{1} X_{t-1}+\cdots----+\beta_{T} X_{t-T}+\varepsilon_{t}(1) \\
& X_{t}=\alpha_{0}+\alpha_{1} X_{t-1}+-----+\alpha_{T} X_{t-T}+\beta_{1} Y_{t-1}+\cdots---+\beta_{T} Y_{t-T}+\mu_{t}(2)
\end{aligned}
$$

Where $T$ is the time lag and $\left(\varepsilon_{t}, \mu_{t}\right)$ are independently and normally distributed random variables with zero mean and constant variance. Our result reported in Tablo 3. 
Table 3. Granger Causality Test Results.

Sample: 2/16/2015 1/08/2018

Lags: 2

\begin{tabular}{lccl}
\hline \hline Null Hypothesis: & Obs & F-Statistic & Prob. \\
\hline \hline CRD does not Granger Cause MS & 150 & 1.67627 & 0.1907 \\
MS does not Granger Cause CRD & & 6.20106 & $0.0026^{* * *}$ \\
\hline
\end{tabular}

Note: $* * *, * *$ and $*$ indicate the $1 \%, 5 \%$ and $10 \%$ levels of significance. A lag of $\mathrm{r}=2$ for VAR was selected before Granger Causality test.

\section{Error Correction Model: Short Run Analyses}

The basis of the error correction mechanism is the assumption of a long-term equilibrium relationship among economic variables. In the error correction model, differences of non-stationary variables are taken, and error correction parameter is included as an explanatory variable, which shows long-run equilibrium agreement between variables.

The fact that the error correction coefficient has a negative sign means that the shocks will come to the balance in the long run. Accordingly, the delay value (1) of the error terms obtained from the 1 th equation is added to the calculus as an independent variable in the equation (2) we used in the next step. Findings obtained using the error correction model are summarized in Table 4.

$$
\Delta M s_{t}=\beta_{0}+\beta_{1} \Delta M s_{-1_{t}}+\beta_{2} \Delta C R D_{t}+e c m_{-1}+\varepsilon_{t-1}
$$

Where $\Delta$ first difference equation given by (1), $\beta 0 \ldots \beta 2$ is the parameter values in the intersection and independent variables, respectively. Here, when et represents the error tem, ecm represents the error correction term. 


\section{Table 4.}

Dependent Variable: DMS

Method: Least Squares

Sample (adjusted): 3/30/2015 1/08/2018

Included observations: 146 after adjustments

\begin{tabular}{lllll}
\hline \hline Variable & Coefficient & Std. Error & t-Statistic & Prob. \\
\hline \hline C & 3805.222 & 33911.57 & 0.112210 & 0.9108 \\
DCRD(-4) & -0.061405 & 0.098164 & -0.625536 & 0.5327 \\
DCRD(-5) & 0.151476 & 0.073121 & 2.071576 & $0.0403 * *$ \\
DMS $_{-1}(-4)$ & -0.103338 & 0.085698 & -1.205829 & 0.2300 \\
DMS-1(-5) & -0.038276 & 0.066346 & -0.576914 & 0.5650 \\
ECM(-1) & -0.856153 & 0.087382 & -9.797827 & $0.0000 * * *$ \\
\hline \hline R-squared & 0.484743 & Durbin-Watson stat & 2.030889 \\
Adjusted R-squared & 0.433997 & Prob(F-statistic) & 0.000000
\end{tabular}

Note: $* * *, * *$ and $*$ indicate the $1 \%, 5 \%$ and $10 \%$ levels of significance

\section{Results}

According to the results of the Granger causality test, in the long run, the direction of causality between the money supply and credit expansion is straightforward from the money supply to the credit extension.

According to the findings of the error correction model, there is a positive and statistically significant relationship between money supply and credit expansion in the short term. Credit expansion increases money supply.

The fact that the error correction term is negative and statistically significant indicates that the model has stable equilibrium.

As a results, the CBRT, as the lender of last resort, accommodates to the borrowing demands of banks, setting the cost of borrowing rather than its quantity. If the Central Bank 
refuses to lend to banks, money markets will collapse and a credit crunch will occur. Therefore, the Central Bank cannot control the money supply in the short run, but can effect the cost of credit through interest rate policy.

\section{Literature}

Ahmad, N. F. Ahmed (2006). The Long-run and Short-run Endogeneity of Money Supply in Pakistan: An Empirical Investigation. SBP-Research Bulletin. Volume 2. Number 1. 2006.

CBRT (2013). Enflasyon ve Fiyat İstikrarı, Türkiye Cumhuriyet Merkez Bankas1, http://www.tcmb.gov.tr/wps/wcm/connect/06084069-3751-44a3-ba98fc5a65b908ba/Enflasyon_FiyatIstikrari.pdf?MOD=AJPERES\&CACHEID $=$ ROOTWO RKSPACE-06084069-3751-44a3-ba98-fc5a65b908ba-m5lk8Dx)

Cepni, O., İ. E. Güney (2017). Endogeneity of Money Supply: Evidence from Turkey. Journal of Finance \& Banking Studies 6(1), https://doi.org/10.20525/ijfbs.v6i1.680

Choi, W. G, S. Oh (2000). Endegeneous Money Supply and Money Demand. IMF working paper. No. 188. IMF Institute. November.

Dickey, D. A., W.A. Fuller (1979). Distribution of the Estimators for Autoregressive Time Series with a Unit Root. Journal of the American Statistical Association, 74.

Granger, C. W. J. (1969). Investigating Causal Relationship by Econometric Models and Cross Special Methods. Econometrica, 37, 3.

Nayan. S., N. Kadir, M. S. Abdullah, M. Ahmad (2013). Post Keynesian Endogeneity of Money Supply: Panel Evidence. Procedia Economics and Finance 7. International Conference on Economics and Business Research 2013 (ICEBR 2013)

Palley, T. (2008). Endogenous Money: Implications for the Money Supply Process, Interest Rates, and Macroeconomics. PERI Working Paper. No. 178. University of Massachusetts Amherst, Poltical Economy Research Institute. 